Abstracta Iranica Iranica

Revue bibliographique pour le domaine irano-aryen

Volume 34-35-36 | 2017

Comptes rendus des publications de 2011-2013

\title{
Jean-Claude Haelewyck. L'inscription phénicienne de Tabnit (KAI 13). Essai de vocalisation
}

\section{Astrid Nunn}

\section{(2) OpenEdition}

1 Journals

\section{Édition électronique}

URL : http://journals.openedition.org/abstractairanica/41552

DOI : 10.4000/abstractairanica.41552

ISSN : 1961-960X

Éditeur :

CNRS (UMR 7528 Mondes iraniens et indiens), Éditions de l'IFRI

Référence électronique

Astrid Nunn, "Jean-Claude Haelewyck. L'inscription phénicienne de Tabnit (KAl 13). Essai de vocalisation », Abstracta Iranica [En ligne], Volume 34-35-36 | 2017, document 26, mis en ligne le 15 juillet 2016, consulté le 05 octobre 2020. URL : http://journals.openedition.org/abstractairanica/41552 ; DOI : https://doi.org/10.4000/abstractairanica.41552

Ce document a été généré automatiquement le 5 octobre 2020.

Tous droits réservés 


\title{
Jean-Claude Haelewyck. L'inscription phénicienne de Tabnit (KAI 13). Essai de vocalisation
}

\author{
Astrid Nunn
}

\section{RÉFÉRENCE}

Jean-Claude Haelewyck. «L'inscription phénicienne de Tabnit (KAI 13). Essai de vocalisation ». Res Antiquae, VIII, 2011, p. 151-161.

1 Comme on le sait, le fait que les voyelles courtes ne soient pas écrites dans les langues sémitiques et qu'elles soient ainsi interprétables de différentes manières, a conduit à de nombreux débats. En partant de la similarité entre le phénicien et l'hébreu l'A. revoit la vocalisation de la fameuse inscription que Tabnit, roi des Sidoniens à la fin de l'époque achéménide, a fait écrire sur son sarcophage.

\section{AUTEURS}

\section{ASTRID NUNN}

Université de Munich 